\title{
Selection of housekeeping genes as internal controls for quantitative RT-PCR analysis of the veined rapa whelk (Rapana venosa)
}

\author{
Hao Song ${ }^{1,2}$, Xin Dang ${ }^{3}$, Yuan-qiu He ${ }^{3}$, Tao Zhang ${ }^{\text {Corresp.. }}{ }^{1,4}$, Hai-yan Wang ${ }^{\text {Corresp. } 1,4}$ \\ ${ }^{1}$ CAS Key Laboratory of Marine Ecology and Environmental Sciences, Institute of Oceanology, Chinese Academy of Sciences, Qingdao, China \\ 2 University of Chinese Academy of Sciences, Beijing, China \\ 3 College of fisheries, Ocean University of China, Qingdao, China \\ 4 Laboratory for Marine Ecology and Environmental Science, Qingdao National Laboratory for Marine Science and Technology, Qingdao, China \\ Corresponding Authors: Tao Zhang, Hai-yan Wang \\ Email address: tzhang@qdio.ac.cn, haiyanwang@qdio.ac.cn
}

Background. The veined rapa whelk Rapana venosa is an important commercial shellfish in China and quantitative real-time PCR (qRT-PCR) has become the standard method to study gene expression in $R$. venosa. For accurate and reliable gene expression results, qRT-PCR assays require housekeeping genes as internal controls, which display highly uniform expression in different tissues or stages of development. However, to date no studies have validated housekeeping genes in $R$. venosa for use as internal controls for qRT-PCR.

Methods. In this study, we selected the following 13 candidate genes for suitability as internal controls: elongation factor-1 $\alpha(E F-1 \alpha), \alpha$-actin $(A C T)$, cytochrome c oxidase subunit 1 (COX1), nicotinamide adenine dinucleotide dehydrogenase (ubiquinone) $1 \alpha$ subcomplex subunit 7 (NDUFA7), 60S ribosomal protein L5 $(R L 5), 60$ S ribosomal protein L28 (RL28), glyceraldehyde 3-phosphate dehydrogenase (GAPDH) , $\beta$-tubulin (TUBB), 40S ribosomal protein S25 (RS25), 40S ribosomal protein S8 (RS8), ubiquitinconjugating enzyme E2 (UBE2), histone H3 (HH3), and peptidyl-prolyl cis-trans isomerase A (PPIA). We measured the expression levels of these 13 candidate internal controls in eight different tissues and twelve larvae developmental stages by qRT-PCR. Further analysis of the expression stability of the tested genes was performed using GeNorm and RefFinder algorithms.

Results. Of the 13 candidate genes tested, we found that $E F-1 \alpha$ was the most stable internal control gene in almost all adult tissue samples investigated with $R L 5$ and $R L 28$ as secondary choices. For the normalization of a single specific tissue, we suggested that EF-1 $\alpha$ and NDUFA7 are the best combination in gonad, as well as COX1 and RL28 for intestine, EF-1 $\alpha$ and $R L 5$ for kidney, EF-1 $\alpha$ and COX1 for gill, EF$1 \alpha$ and $R L 28$ for Leiblein and mantle, EF-1 $\alpha, R L 5$, and NDUFA7 for liver, GAPDH, PPIA, and RL28 for hemocyte. From a developmental perspective, we found that $R L 28$ was the most stable gene in all developmental stages measured, and COX1 and $R L 5$ were appropriate secondary choices. For the specific developmental stage, we recommended the following combination for normalization, $P P I A, R S 25$, and $R L 28$ for stage $1, R L 5$ and $R L 28$ for stage 2 and 5, RL28 and NDUFA7 for stage 3, and PPIA and TUBB for stage 4 .

Discussion. Our results are instrumental for the selection of appropriately validated housekeeping genes for use as internal controls for gene expression studies in adult tissues or larval development of $R$. venosa in the future. 


\section{Research Article}

2 Selection of housekeeping genes as internal controls for

3 quantitative RT-PCR analysis of the veined rapa whelk

4 (Rapana venosa)

5 Hao Song ${ }^{1,2}$, Xin Dang ${ }^{4}$, Yuan-qiu He ${ }^{4}$, Tao Zhang ${ }^{1,3, *}$, Hai-yan Wang ${ }^{1,3, *}$

$7 \quad{ }^{1}$ CAS Key Laboratory of Marine Ecology and Environmental Sciences, Institute of Oceanology, Chinese

8 Academy of Sciences, Qingdao, China

92 University of Chinese Academy of Sciences, Beijing, China

$10{ }^{3}$ Laboratory for Marine Ecology and Environmental Science, Qingdao National Laboratory for Marine

11 Science and Technology, Qingdao, China

$12{ }^{4}$ College of fisheries, Ocean University of China, Qingdao, China

Corresponding Authors at: 7 Nanhai Road, Qingdao, Shandong 266071, People's Republic of China. 


\section{ABSTRACT}

Background. The veined rapa whelk Rapana venosa is an important commercial shellfish in China and quantitative real-time PCR (qRT-PCR) has become the standard method to study gene expression in $R$. venosa. For accurate and reliable gene expression results, qRT-PCR assays require housekeeping genes as internal controls, which display highly uniform expression in different tissues or stages of development. However, to date no studies have validated housekeeping genes in $R$. venosa for use as internal controls for $\mathrm{qRT}-\mathrm{PCR}$.

Methods. In this study, we selected the following 13 candidate genes for suitability as internal controls: elongation factor- $1 \alpha(E F-1 \alpha), \alpha$-actin $(A C T)$, cytochrome c oxidase subunit $1(C O X 1)$, nicotinamide adenine dinucleotide dehydrogenase (ubiquinone) 1 a subcomplex subunit 7 (NDUFA7), 60S ribosomal protein L5 (RL5), 60S ribosomal protein L28 ( $R L 28)$, glyceraldehyde 3-phosphate dehydrogenase (GAPDH), $\beta$-tubulin (TUBB), 40S ribosomal protein $\mathrm{S} 25(R S 25), 40 \mathrm{~S}$ ribosomal protein S8 (RS8), ubiquitin-conjugating enzyme E2 (UBE2), histone H3 (HH3), and peptidyl-prolyl cis-trans isomerase A $(P P I A)$. We measured the expression levels of these 13 candidate internal controls in eight different tissues and twelve larvae developmental stages by qRT-PCR. Further analysis of the expression stability of the tested genes was performed using GeNorm and RefFinder algorithms.

Results. Of the 13 candidate genes tested, we found that $E F-1 \alpha$ was the most stable internal control gene in almost all adult tissue samples investigated with $R L 5$ and $R L 28$ as secondary choices. For the normalization of a single specific tissue, we suggested that $E F-1 \alpha$ and NDUFA7 are the best combination in gonad, as well as $C O X 1$ and $R L 28$ for intestine, $E F-1 \alpha$ and $R L 5$ for kidney, $E F-1 \alpha$ and $C O X 1$ for gill, $E F-1 \alpha$ and $R L 28$ for Leiblein and mantle, $E F-1 \alpha, R L 5$, and NDUFA7 for liver, $G A P D H, P P I A$, and $R L 28$ for hemocyte. From a developmental perspective, we found that $R L 28$ was the most stable gene in all developmental stages measured, and COX1 and RL5 were appropriate secondary choices. For the specific developmental stage, we recommended the following combination for normalization, PPIA, RS25, and $R L 28$ for stage $1, R L 5$ and $R L 28$ for stage 2 and 5, RL28 and NDUFA7 for stage 3, and PPIA and TUBB for stage 4.

Discussion. Our results are instrumental for the selection of appropriately validated housekeeping genes for use as internal controls for gene expression studies in adult tissues or larval development of $R$. venosa in the future. 


\section{INTRODUCTION}

Gene expression analysis has great utility in increasing our understanding of gene function that underlies all biological and developmental processes. Presently available approaches or methods to evaluate gene expression include RNA in situ hybridization, northern blotting, microarray analysis, transcriptome sequencing, and quantitative real-time PCR (qRT-PCR). Heid et al. (1996) first proposed using qRT-PCR as a novel quantitative method to detect transcript levels of genes. Recently, qRT-PCR has become a common method to analyze gene expression on account of its excellent sensitivity, specificity, reproducibility, and extensive dynamic range (Bustin et al. 2005; Kubista et al. 2006).

Despite its advantages, the quality of data obtained from using this approach is dependent on RNA quality, the efficiency of reverse transcription, and appropriate normalization (Bustin et al. 2009). Therefore, relative qRT-PCR assay necessitates internal reference controls, which are mostly housekeeping genes. Housekeeping genes are constitutive genes that express proteins necessary to maintain elementary cellular functions. Because they have no organ or tissue specificity and are not affected in pathophysiological conditions, housekeeping genes should exhibit stable expression levels under various experimental conditions and in different tissues and developmental stages (Butte et al. 2002; Eisenberg \& Levanon 2003). Several housekeeping genes with relatively constant expression are considered as internal controls in qRT-PCR. These include glyceraldehyde 3-phosphate dehydrogenase $(G A P D H)$, ribosomal protein $(R P)$, tubulin $(T U B)$, actin $(A C T)$, elongation factor $(E F)$, ubiquitin $(U B Q)$, and histone $\mathrm{H} 3$ (HH3) (Bangaru et al. 2012; Huggett et al. 2005; Lee et al. 2010; Ray \& Johnson 2014). However, various studies have reported that internal standards, mainly housekeeping genes used in quantifying mRNA expression, exhibit variable expression levels under different tissue types, developmental stages, and environmental conditions (Stürzenbaum \& Kille 2001; Thellin et al. 1999). Because selection of the appropriate internal control relies on the type of samples measured in the experiment, it is necessary to identify and characterize housekeeping genes which are essential for qRT-PCR data normalization in the experiment in question.

The veined rapa whelk Rapana venosa, which is an economically important mollusk in China, has been bred since 1992 (Yuan 1992). In France, Argentina, and the United States, R. venosa is considered an invasive pest that severely disrupts the survival of native bivalves because of its lack of human consumption (Culha et al. 2009; Giberto et al. 2006; Leppäkoski et al. 2002; Mann \& Harding 2003; Mann et al. 2006). Because of its commercial importance and ecological impact, molecular research in the morphology and biology of $R$. venosa have been increasing, and qRTPCR is commonly being used as the tool to study gene expression (Lusumin et al. 2008; Samadi $\&$ Steiner 2009). Housekeeping genes need to be identified and validated as reliable reference genes, however, no such prior study has been carried out in $R$. venosa. Thus, the objective of this reference-selection study is to evaluate 13 candidate reference genes associated with eight target tissues and 12 developmental stages in $R$. venosa.

\section{MATERIALS AND METHODS}

\section{Larvae culture and sample collection}

Egg capsules of $R$. venosa were collected naturally from Laizhou Bay, Laizhou, China. Following published methods, larvae were incubated in appropriately sized tanks at Blue Ocean Co. Limited (Laizhou, China) (Pan et al. 2013). Newly hatched pelagic larvae were transferred to $2.5 \mathrm{~m} \times 2.5 \mathrm{~m} \times 1.5 \mathrm{~m}$ tanks with a density range of $0.3-0.05 \mathrm{ind} / \mathrm{mL}$, determined by developmental 
stage. Larvae were fed a mixture of microalgae containing Platymonas subcordiformis, Isochrysis galbana, and Chlorella vulgaris $\left(13.0 \times 10^{4} \mathrm{cells} / \mathrm{mL}\right.$ daily $)$. Seawater was treated by sand filtration and UV irradiation before samples were cultured. Seawater temperature was below $25 \pm$ $1^{\circ} \mathrm{C}$. Larvae samples were examined by microscope to ensure synchronous growth in developmental stages including blastula, juvenile, and adult stages. Samples were collected and washed with distilled water, frozen in liquid nitrogen, and stored at $-80{ }^{\circ} \mathrm{C}$ until use. We selected five biological replicates from 12 larval stage [(blastula (L), gastrula (M), trochophore (N), early intra-membrane veliger (R), mid intra-membrane veliger $(\mathrm{S})$, late intra-membrane veliger $(\mathrm{T})$, onespiral whorl larvae (C), two-spiral larvae (D), early three-spiral whorl larvae (F), late three-spiral whorl larvae $(\mathrm{G})$, four-spiral whorl larvae $(\mathrm{J})$, and juvenile stage $(\mathrm{Y})$ ] and all tested tissues (gill, hemocyte, intestine, Leiblein's gland, liver, kidney, mantle, and gonad) were aseptically dissected from five adult specimens. Hemolymph was extracted from the pericardial cavity using a $1 \mathrm{~mL}$ medical injector. Hemocytes were obtained by centrifugation at $4{ }^{\circ} \mathrm{C}$ and $1,000 \times \mathrm{g}$ for $10 \mathrm{~min}$.

\section{Total RNA extraction and cDNA synthesis}

Total RNA was extracted from tissue samples of gill, intestine, Leiblein's gland, liver, kidney, and gonad, and from larvae of different developmental stages using MiniBEST Universal RNA Extraction Kit (TaKaRa, Tokyo, Japan), and from hemocyte and mantle using RNAiso Plus (TaKaRa) according to manufacturer's instructions. RNA integrity was confirmed by gel electrophoresis based on the predicted product size. RNA from each sample was diluted with nuclease-free water and $0.1 \mu \mathrm{g}$ RNA of each sample was used as the template for cDNA synthesis using a PrimeScript ${ }^{\mathrm{TM}}$ RT reagent Kit with gDNA Eraser (TaKaRa). Prior to qRT-PCR, cDNA was diluted 10-fold.

\section{Selection of candidate internal controls}

According to RNA-seq transcriptome data of developmental samples, which were derived from stages $\mathrm{C}$ to $\mathrm{Y}$ and performed in triplicate for each stage (Song et al. 2016), genes with similar expression patterns were identified and classified to different clusters. Candidate housekeeping genes were selected from clusters exhibiting expression stability based the RPKM value in different developmental stages. In total, 13 genes were selected using a previously published RNAseq data (Song et al 2016).

\section{Primer design and $q R T-P C R$}

The primers for qRT-PCR were designed using Primer Premier 5 (PREMIER Biosoft, USA) and are listed in Table 1. qRT-PCR was performed using a SYBR Green ${ }^{\circledR}$ real-time PCR assay consisting of a SYBRPrimeScript ${ }^{\text {TM }}$ RT-PCR Kit II (TaKaRa) with a Mastercycler ${ }^{\circledR}$ ep realplex S (Eppendorf, Hamburg, Germany). Amplifications were carried out in a total volume of $20 \mu \mathrm{L}$ [10 $\mu \mathrm{L}$ of SYBR Green Master Mix, $0.4 \mu \mathrm{L}$ of each forward and reverse primer $(10 \mu \mathrm{mol} / \mathrm{L}), 1 \mu \mathrm{L}$ of diluted cDNA, and 8.2 $\mu \mathrm{L}$ RNase-free water] as follows: $95^{\circ} \mathrm{C}$ for $2 \mathrm{~min}$ followed by 40 cycles of $95{ }^{\circ} \mathrm{C}$ for $15 \mathrm{~s}$, the respective annealing temperature $(\mathrm{Tm})$ for $15 \mathrm{~s}$, and $68{ }^{\circ} \mathrm{C}$ for $20 \mathrm{~s}$. The Tm for $G A P D H, E F-1 \alpha, A C T, C O X 1, N D U F A 7$, and $R L 5$ is $58.5^{\circ} \mathrm{C}$, the Tm for RL28, TUBB, RS25, RS 8 , $U B E 2$, and PPIA is $57.5^{\circ} \mathrm{C}$, and the Tm for $H H 3$ is $56.5^{\circ} \mathrm{C}$. Melting-curve analysis of the amplification products was performed and following electrophoresis each gel picture was analyzed to confirm the product by the predicted size. Each assay was performed in triplicate and Cq values were recorded for further analysis.

\section{Analysis of gene expression stability}


The expression stability of 13 candidate housekeeping genes among the different RNA samples was calculated using the Excel-based tool GeNorm v3.4 (https://genorm.cmgg.be/) and overall stability of these candidate genes was determined using RefFinder (http://fulxie.0fees.us/?type=reference\&i=1). We used this suite of tools to ensure a statistically thorough analysis and robust identification of housekeeping genes for use in qRT-PCR of $R$. venosa.

GeNorm evaluates gene stability (M) of inputted genes using a statistical algorithm according to geometric averaging of multiple control genes and means pairwise variation of a gene from those remaining control genes in all provided samples. Vandesompele et al. (2002) proposed a value of 1.5 as a cut-off for suitability as an endogenous control, especially with heterogeneous samples such as different cell types or tissues. Based on this approach, genes with the lowest $\mathrm{M}$ value have the highest expression stability. The best combinations of two internal control genes with a constant level were selected by stepwise exclusion of the gene with the highest $\mathrm{M}$ value followed by a recalculation of new $\mathrm{M}$ values for all of the remaining genes (Vandesompele et al. 2002). In addition, GeNorm is used to determine the optimal number of housekeeping genes by pairwise number variation analysis. It computes the geometric mean of the selected genes that are expressed steadily for accurate normalization. A pairwise variation below 0.15 , which is determined by $\mathrm{Vn} / \mathrm{n}+1$, means that an added control gene $(n+1)$ would not further improve the normalization factor (Vandesompele et al. 2002).

RefFinder is an online analysis tool, which includes GeNorm v3.4, NormFinder v20, BestKeeper v1, and delta CT, that is used to avoid one-sidedness and the potential limitations of relying on a single tool or algorithm for stability analysis to identify reference genes of interest (Pfaffl et al. 2004). Andersen et al. (2004) developed NormFinder to estimate both overall and subgroup variation of the sample set of candidate genes for normalization factors (NFs) in a gene expression study. Three candidate housekeeping genes and two tested samples per group are required to set the minimum input data. Raw Cq values are first log-transformed and used as input. Random co-regulated genes would not bias the results of the software. NormFinder ranks the best candidate reference genes according to the lowest expression stability values and the lowest variation values by combining intra- and inter-group variability.

BestKeeper calculates descriptive statistics of the Cq values and Pearson correlation coefficient (Pfaffl et al. 2004). Internal control genes with stable expression for use as a housekeeping gene are identified based on highly correlated expression levels. The correlation between each candidate reference gene and the BestKeeper index, which is determined by calculating the geometric mean of the $\mathrm{Cq}$ values of the candidate genes, is estimated by the Pearson correlation coefficient (r), the coefficient of determination $\left(\mathrm{r}^{2}\right)$, and $\mathrm{P}$ value. BestKeeper ranks the candidate housekeeping genes according to $\mathrm{Cq}$ variation, which is displayed as standard deviation (SD), $r$, and as $\mathrm{r}^{2}$ with the BestKeeper index value. An SD threshold value less than 1.0 is recommended by Pfaffl et al. (2004) and the closer $r^{2}$ is to 1 , the better.

\section{RESULTS}

\section{Selection of housekeeping genes to be used as internal controls}

Eight different subclusters that exhibited various gene expression patterns were identified. Genes that have similar gene expression patterns were evaluated based on their correlation and classified as a single subcluster (Fig. 1). We found that each subcluster had between 179 and 8222 genes. The gene expression patterns of subclusters 1 and 8 were highly variable in six developmental 
182

183

184

185

186

stages, whereas genes in subclusters 2, 3, and 4 indicated the greatest expression stability. Therefore, genes from these latter subclusters were selected as eligible candidate housekeeping genes. $T U B B$, which is a common housekeeping gene already used as an internal control, was selected from subcluster 2. $A C T, U B E 2$, and $G A P D H$ were selected from subcluster 3, while the other nine candidate housekeeping genes were from subcluster 4.

\section{Real-time PCR amplification of housekeeping genes}

Single peaks of the melting curves in different samples confirmed primer accuracy and genespecific amplification (Fig. S1). In addition, agarose gel electrophoresis exhibited a single band for each amplified gene and PCR product were confirmed based on the expected size.

\section{Gene expression stability analysis in tissues}

In our study, we identified 13 candidate reference genes and tested them for expression stability in eight different tissues, specifically, gill, hemocyte, intestine, Leiblein's gland (Leiblein), liver, kidney, mantle, and gonad from five adult individuals.

We analyzed the raw quantification cycle data (Cq values) obtained from qRT-PCR and the determined variation among these candidate housekeeping genes in trial samples. In all tissues, we found that the average $\mathrm{Cq}$ values of the 13 genes ranged from 14.71 to 33.45 (Table.2). We found that $C O X 1$ had the lowest mean Cq values, which represent the highest expression levels, both in all tissues and in individual tissues, whereas HH3 had the highest mean Cq values, which indicates the lowest expression levels, in various tissues with the exception of the mantle. We found that each housekeeping gene displayed minor variability in its expression level in the various tissues under the same conditions. According to computed values of standard error (SE), we found that $R L 28(\mathrm{SE}=0.37), E F-1 \alpha(\mathrm{SE}=0.38), N D U F A 7(\mathrm{SE}=0.39)$, and $R S 25(\mathrm{SE}=0.39)$ have the least varying transcript abundance values when all of the tissues were analyzed together; however, we found that different housekeeping genes displayed variable levels of transcript abundance in different tissues. The genes with the lowest $\mathrm{SE}$ in the eight tissues examined was $R S 25$ ( $\mathrm{SE}=0.26)$ in gill, $T U B B(\mathrm{SE}=0.35$ and $\mathrm{SE}=0.72)$ in hemocyte and Leiblein respectively, $H H 3(\mathrm{SE}=0.44)$ in intestine, $R L 5(\mathrm{SE}=0.44)$ and $R L 28(\mathrm{SE}=0.42)$ in liver, PPIA $(\mathrm{SE}=0.56)$ in kidney, $A C T$ (SE $=0.44)$ and $R S 25(\mathrm{SE}=0.45)$ in mantle, and EF-1 $\alpha(\mathrm{SE}=0.46)$ and NDUFA7 $(\mathrm{SE}=0.47)$ in gonad. These findings demonstrate that no single candidate housekeeping gene is expressed at a stable level on the basis of $\mathrm{Cq}$ value only in these eight tissues from different adult $R$. venosa samples, and therefore, it is necessary to select better-suited housekeeping genes using additional statistical analyses.

The GeNorm-derived $\mathrm{M}$ values of candidate housekeeping genes in all tissues and for each tissue are shown in Fig. 2. We found that $E F-1 \alpha$ and $R L 5$ (both $\mathrm{M}=0.52$ ) showed the highest stability in all tissues as well as in gonad, kidney, and liver. However, we found that $E F-1 \alpha$ and $R L 28$ were the best combination of two internal control genes for gill, intestine, and mantle, whereas the best control gene pairs for hemocyte and Leiblein were PPIA and HH3, and RL28 and $U B E 2$, respectively. These results indicate that $E F-1 \alpha, R L 5$, and $R L 28$ are the most appropriate internal control genes for most tissues.

Fig. 2 also shows a ranking of the stability values calculated by NormFinder for tissue-specific housekeeping genes. The best housekeeping genes on the basis of all tissues together was $E F-1 \alpha$ with a stability value of 0.63 as well as in Leiblein and mantle ( 0.16 and 0.10 , respectively), whereas in the gill and intestine it was $C O X 1$ ( 0.08 and 0.20 , respectively), in hemocyte and gonad it was $R L 28$ ( 0.68 and 0.84 , respectively), and in liver and kidney it was both $R L 5$ and $E F-1 \alpha$ (both 
226

227

228

229

230

231

232

233

234

235

236

237

238

239

240

241

242

243

244

245

246

247

248

249

250

251

252

253

254

255

256

257

258

259

260

261

262

263

264

265

266

267

268

269

270

271

0.17 and 0.05 , respectively). Based on these findings, $E F-1 \alpha$ is an appropriate stable internal control gene for all tissues analyzed either together or separately. In addition, $R L 5, C O X 1$, and $R L 28$ can be used for their respective tissue-specific analyses.

Using SD values generated from BestKeeper for each of the various housekeeping genes, we found major differences in each tissue (shown in Tables 3 and 4). RL28 was identified as the best gene for all tissues together and in liver, whereas $R S 25$ was identified for use in gill and mantle, $T U B B$ in hemocyte and Leiblein, HH3 in intestine, PPIA in kidney, and NDUFA7 in gonad. However, as ranked by r, we found that $E F-1 \alpha$ was the most stably expressed gene in all tissues together and in most separate tissues, namely, gill, Leiblein, mantle, gonad, and kidney, although $E F-1 \alpha$ and $R L 5$ had the same rank position in kidney. In addition, RL5 was the best gene in hemocyte, whereas $C O X 1$ and PPIA were ideal for intestine and liver, respectively. Therefore, based on our findings with r, $E F-1 \alpha$ was the most stable housekeeping gene in most tissue samples.

\section{Gene expression stability analysis in developmental stages}

In this study, using five specimens, we identified 13 candidate reference genes and tested them for expression stability in 12 different developmental larval stages. For data description and display in tables and figures, we merged these 12 developmental larval stages into five groups/stages according to their developmental characteristics: stage $1(\mathrm{~L}, \mathrm{M}, \mathrm{N})$; stage $2(\mathrm{R}, \mathrm{S}, \mathrm{T})$; stage $3(\mathrm{C}$, $\mathrm{D}, \mathrm{F})$; stage $4(\mathrm{G}, \mathrm{J})$; and stage $5(\mathrm{Y})$.

We analyzed the $\mathrm{Cq}$ values obtained from qRT-PCR and calculated variation among the candidate housekeeping genes evaluated in the samples. In all stages combined, the average Cq of the 13 genes ranged from 19.26 to 30.36 (Table 5). We found that $E F-1 \alpha$ and COX1 had the lowest mean Cq values, which represented the highest expression level, in both the total for all stages and separately for each of the five stages, whereas we found that $\mathrm{HH} 3$ had the highest mean Cq values in all of the different stages, which indicates it had the lowest expression levels. Interestingly, stages 1 and 2 showed more variation in gene expression compared to that found in the other stages, and that integral $\mathrm{Cq}$ values decreased gradually from stage 1 to stage 3 and were then constant (Table S1). According to computed SE values, we found that $H H 3$ (SE = 0.32), EF-1 $\alpha$ and NDUFA7 (both $\mathrm{SE}=0.34)$, and $G A P D H(\mathrm{SE}=0.35)$ had the least varying transcript abundance when all stages were analyzed together. However, the tested housekeeping genes showed different expression states in each stage under the same condition. The gene with the lowest $\mathrm{SE}$ value for each of the five stages is $R L 28(\mathrm{SE}=0.31)$ and $C O X 1(\mathrm{SE}=0.32)$ in stage 1, $P P I A(\mathrm{SE}=0.62)$ in stage $2, T U B B$ and $R S 25$ (both $\mathrm{SE}=0.15)$ in stage 3, PPIA and TUBB (both $\mathrm{SE}=0.10)$ in stage 4 , and $R S 25(\mathrm{SE}=0.19)$ in stage 5. These findings illustrate that no single candidate housekeeping gene was expressed at a stable level on the basis of Cq value only across five stages from different $R$. venosa larvae samples, and therefore, further statistical analyses were required to identify the best housekeeping genes.

GeNorm-derived $M$ values of the candidate housekeeping genes for all stages together and stage-specific are shown in Fig. 3. COX1 and RL28 (both $\mathrm{M}=0.34$ ) have the highest stability in all the stages together. However, we found that UBE2 and PPIA were the most suitable combination of two internal controls for stage $1, R L 5$ and $R L 28$ were optimal for stage 2, NDUFA7 and RL28 in stage 3, RS25 and PPIA in stage 4, and COXI and RL5 in stage 5. These results indicate that $R L 28$ is the most appropriate internal control gene for most of the different stages examined. In addition, Fig. 3 shows the ranked stability value calculated by NormFinder of the tested candidate housekeeping genes, and we found that the best housekeeping gene for all combined stages was $R L 28$ with a stability value of 0.188 . It was also the best gene for stages 1 and 3 ( 0.277 and 0.228 , respectively), whereas $R L 5$ was the best gene for stages 2 and 5 with 
272 respective stability values of 0.142 and 0.112 , and $T U B B(0.022)$ for stage 4 . Based on these 273 findings, $R L 28$ and $R L 5$ are the appropriate stable internal control genes for most developmental 274 stages.

275 Based on SD values generated from BestKeeper, we found that various housekeeping genes manifested major differences in expression in each stage (Tables 6 and 4). We identified $H H 3$ as the best gene for all stages together, whereas the best stage-specific genes were $R L 28$ for stage 1, NDUFA7 for stage 2, TUBB for stage 3, and $R S 25$ for stages 4 and 5. However, when ranking by r, we found that $R L 28$ was the most stably expressed gene when all stages were combined and for stage 3 with PPIA, RL5,TUBB, and GAPDH being the ideal genes for stages 1, 2, 4, and 5, respectively.

\section{Determination of the optimal number of internal controls for normalization}

In regards to the tissue-specific pairwise variation calculated by GeNorm (Fig. 4), we found that in most tissues (gill, gonad, intestine, Leiblein, kidney, and mantle) the V4/5 value of 0.141 indicated $E F-1 \alpha$ and $R L 5$ are insufficient for normalization and that $R L 28$ and NDUFA7 should be included; however, the $V 2 / 3$ value was under 0.15 , which suggests two internal control genes were sufficient. In liver, the V2/3 value (0.148) was comparable to the cut-off value although the V $3 / 4$ value (0.092) was sufficiently low, which indicates the inclusion of a third reference gene is needed to improve stability of normalization (Fig.S2). We found that none of the pairwise variations determined before V10/11 was less than 0.15 in hemocyte, and therefore, over 10 genes are suitable as reference genes based on the determined conditions (Figure S4). In terms of pairwise variation for all developmental stages (Fig. 4), we found that the V2/3 value was below threshold (0.15), which suggests $R L 28$ and $C O X 1$ (on the basis of the $\mathrm{M}$ value) are sufficient for normalization, and that inclusion of an additional reference gene is not required in most stages with the exception of stage 1 . We found in stage 1 that the V2/3 value exceeds threshold, whereas V3/4 is below threshold, which indicates the necessity of adding a third reference gene ( $R S 25$ based on M value) to improve the robustness of normalization (Fig.S3).

\section{DISCUSSION}

The commercial importance and ecological role of $R$. venosa have driven increased molecular research towards investigating the morphology and biology of this organism, which may commonly use qRT-PCR as a tool to study gene expression (Lusumin et al. 2008; Samadi \& Steiner 2009). It is imperative to study the expression patterns of specific genes in different larval developmental stages and adult tissues in $R$. venosa, and qRT-PCR is a demonstrably powerful tool to analyze such gene expression. Nevertheless, internal controls are critical to obtain reliable normalization of gene expression, and in turn, robust results from qRT-PCR analysis. The ideal internal control gene is characterized by stable expression across different environmental conditions and physiological states, such as different developmental stages and tissue types. However, according to findings from many related studies, housekeeping genes have variable expression changing under different experimental conditions. Thus, no gene has stable expression under all experimental conditions. As a consequence, using a single control gene in all experimental conditions could influence the accuracy of normalization of gene expression results (Jain et al. 2006). Therefore, evaluating the level of candidate housekeeping genes is a vital preliminary effort to reliably quantifying target genes by qRT-PCR (Bustin 2009; Dheda et al. 2005). Prior to our study, there has been no published finding of research that has examined the suitability of potential housekeeping genes for gene expression analysis in $R$. venosa. We selected 
13 genes as candidate internal controls from high-throughput RNA-seq data of $R$. venosa larvae, which showed high and stable levels of expression, and most of which were currently being used as internal control genes in studies of Mollusca. The expression levels of these 13 genes were monitored by qRT-PCR in eight different tissues and twelve developmental larval stages.

We found from comprehensive analysis using GeNorm, NormFinder, and BestKeeper in eight different tissues analyzed together that $E F-1 \alpha$ was the most stable internal control gene followed by $R L 28$. According to the pairwise variation calculated by GeNorm, two additional genes should be added for normalization. Based on the rank determined by NormFinder and BestKeeper, RS 8 and $R S 25$ are the most appropriate internal controls; however, RL5 and NDUFA7 are determined to be the most appropriate internal controls based on GeNorm. Considering these findings, we conclude that $E F-1 \alpha, R L 28, R L 5$, and $R S 8$ are the most stable gene combination for $R$. venosa tissues. EF- $1 \alpha$ belongs to the G-protein family, which has a significant influence in protein translation (Browne \& Proud 2002; Ejiri 2002). EF-1 $\alpha$ was the most stable reference gene in studies of disk abalone exposed to tributyltinchloride and 17 $\beta$-estradiol (Wan et al. 2011), in Atlantic salmon (Nilsen et al. 2005), during larval development in flatfish (Infante et al. 2008), in hemocytes of flat oyster Ostrea edulis (Morga et al. 2010), and in different stages of gametogenesis in the mussel, Mytilus edulis (Cuberoleon et al. 2012). RL5 and RL28 belong to the large subunit ribosomal protein family, while RS8 and RS25 belong to the small subunit family, and they are present in all cell types involved in biogenesis of new proteins. Studies found that RL5 was the most stable gene in all tissues in red abalone (López-Landavery et al. 2014) and in disk abalone following exposure to tributyltinchloride and 17 $\beta$-estradiol (Wan et al. 2011). The other genes relating to ribosomal protein biosynthesis are commonly considered as housekeeping genes in many other organisms, including animals, plants, and algae (Barsalobres-Cavallari et al. 2009; Hsiao et al. 2001; Liu et al. 2012). RL7 and $R S 18$ maintain considerable expression stability in both OsHV-1 infected and uninfected pacific oyster larvae (Du et al. 2013). RS18 was the most stable gene in Mya arenaria after Vibro splendidus 7SHRW challenge (Mateo et al. 2010) and in the intestine of the sea cucumber, Apostichopus japonicas, during normal growth and aestivation (Zhao et al. 2014).

In addition, using GeNorm, NormFinder, and BestKeeper we identified tissue-specific expression levels of 13 candidate internal controls in eight different tissues to determine the most stable gene for each tissue type. We found that $E F-1 \alpha$ and NDUFA7 are the best combination for normalization in gonad. For gill, $E F-1 \alpha$ and $C O X 1$ are the best combination. COX1, which is encoded from an approximately $650 \mathrm{bp}$ fragment of the mitochondrial gene, is used to identify animals and plants (Evans et al. 2007), but has been rarely used as an internal control of gene expression (Kaweesi et al. 2014). However, in this study, we found it demonstrates relatively stable expression and in fact can be the secondary internal control for $R$. venosa tissues and developmental stages. In addition, we identified $C O X 1$ and $R L 28$ for intestine, $E F-1 \alpha$ and $R L 5$ for kidney, and $E F-1 \alpha$ and $R L 28$ for Leiblein and mantle. For liver, we determined from our analysis that at least three internal controls are required for reliable normalization, which are $E F-1 \alpha, R L 5$, and NDUFA7. In regards to hemocyte, we determined based on pairwise variation that more than 10 genes should be used as reference genes, and therefore, we proposed using as many internal controls available including $G A P D H, P P I A$, and $R L 28$. Because of our comprehensive assessment, it is evident that $E F-1 \alpha$ is a good housekeeping gene as an internal control in most $R$. venosa tissues and for a particular tissue, we recommend including additional corresponding housekeeping genes to improve stability. 
Comprehensive analysis using GeNorm, NormFinder, and BestKeeper combining different developmental stages in $R$. venosa identified $R L 28$ and $R L 5$ as the most stable gene combination for normalization, a finding that is supported from an assessment of the pairwise variation. In contrast, three genes are required for normalization in stage 1, namely, PPIA, RS25, and RL28. PPIA has been used as an internal control on account of its stable expression in milk somatic cells under healthy and disease status (Jarczak et al. 2014). Furthermore, PPIA was also found to be a stable reference gene in the mammary gland of goats, murines, and bovines (Bonnet et al. 2013; Boutinaud et al. 2004; Robinson et al. 2007). With the exception of stage 1, the other four stages require two genes for normalization, specifically, $R L 5$ and $R L 28$ for stage 2 and stage $5, R L 28$ and NDUFA7 for stage 3, and PPIA and TUBB for stage 4. Both $\alpha$-tubulin (TUBA) and TUBB belong to the tubulin family of proteins, and are considered suitable internal controls in research because of their high expression stability. TUBB was found to be the most stable gene in different developmental stages of Hippoglossus hippoglossus (Fernandes et al. 2008) and in goat follicles (Costa et al. 2012). In addition, two isoforms of TUBB (TUB1 and TUB5) are used as control genes in Striga hermonthica (Fernández-Aparicio et al. 2013). Interestingly, in the current study, we found that $T U B B$ showed significantly different expression stability in $R$. venosa. TUBB was the least stable gene when all tissues and stages were assessed together as well as in gonad and gill, whereas in contrast it was the most stable gene in stage 4 . This difference illustrates the importance of studies such as ours to identify and evaluate species-specific housekeeping genes for qRT-PCR as differences in expression of the same gene exists between different species. Based on our findings, we determined that $R L 28$ was an appropriate housekeeping gene for use as an internal control for qRT-PCR during most developmental stages of $R$. venosa larvae. Furthermore, we propose that $R L 5$ and other specific genes can be included in normalization as needed for the corresponding developmental stage.

$G A P D H, A C T, U B E 2$, and $H H 3$ are housekeeping genes that are considered as internal controls for qRT-PCR in both plants and animals. However, these genes showed unsuitability as internal controls in $R$. venosa adult tissues and larvae development in our study. GAPDH is expressed stably under different tissue types in Crassostrea gigas (Dheilly et al. 2011) and hence it was selected as internal control for qRT-PCR analysis of $R$. venosa in previous study (Song et al. 2016). According to present result, GAPDH is not recommended as internal control for future studies involved with $R$. venosa adult tissues and larvae development. As to $H H 3$, in this study, we identified it according to GeNorm and NormFinder as the least stable gene for most tissues (intestine, kidney, Leiblein, liver, and mantle) and for stages 1 and 2. These results demonstrate that $H H 3$ is unsuitable to be used as an internal control in $R$. venosa.

So far, there is no ideal internal control that can be fully used for various types of samples with constant expression. Usually, housekeeping genes have variable expression changing under different conditions. As a consequence, using a single control gene in all experimental conditions could influence the accuracy of normalization of gene expression results (Jain et al. 2006). To eliminate bias and variation of these, Vandesompele et al. (2002) suggested to use three control genes to correct during normalization at least. Therefore, in order to investigate the expression of target gene, researchers should take all conditions into account, including types of sample, species, gene family and experiment conditions, and choose suitable and stable gene to normalize to acquire reliable data.

\section{CONCLUSIONS}


405

406

407

408

409

410

411

412

413

414

415

416

417 The following abbreviations are used in this manuscript:

\begin{tabular}{|l|l|}
\hline qRT-PCR & quantitative real-time PCR \\
\hline EF-1 $\alpha$ & elongation factor-1 $\alpha$ \\
\hline ACT & $\alpha$-actin \\
\hline COX1 & cytochrome c oxidase subunit 1 \\
\hline NDUFA7 & $\begin{array}{l}\text { nicotinamide adenine dinucleotide dehydrogenase } \\
{[\text { ubiquinone] } 1 \alpha \text { subcomplex subunit } 7}\end{array}$ \\
\hline RL5 & 60S ribosomal protein L5 \\
\hline RL28 & 60S ribosomal protein L28 \\
\hline GAPDH & glyceraldehyde 3-phosphate dehydrogenase \\
\hline TUBB & $\beta$-tubulin \\
\hline RS25 & 40S ribosomal protein S25 \\
\hline RS8 & 40S ribosomal protein S8 \\
\hline UBE2 & ubiquitin-conjugating enzyme E2 \\
\hline HH3 & histone H3 \\
\hline PPIA & peptidyl-prolyl cis-trans isomerase A \\
\hline Cq values & quantification cycles \\
\hline Leiblein & Leiblein's gland \\
\hline
\end{tabular}
normalization in $R$. venosa tissues and larvae developmental stages. In our assessment of tissuespecific genes, $E F-1 \alpha$ was the most stable internal control gene in most tissue samples tested with $R L 5$ and $R L 28$ as suitable secondary choices. We found that $R L 28$ was the most stable gene when evaluating all measured developmental stages, and COX1 and RL5 were appropriate secondary choices. To our knowledge, this study was the first to investigate and identify optimal housekeeping genes for relative quantification of qRT-PCR in $R$. venosa. The results of this study provide not only references to estimate gene expression levels during $R$. venosa larvae developmental stages, but also enables future research efforts to measure readily and robustly tissue-specific mRNA abundance in $R$. venosa.

\section{Abbreviations}

We identified and evaluated expression stability of 13 housekeeping genes for qRT-PCR 
419

420

421

422

423

424

425

426

427

428

429

430

431

432

433

434

435

436

437

438

439

440

441

442

443

444

445

446

447

448

449

450

451

452

453

454

455

456

457

458

459

460

461

462

463

464

\section{REFERENCES}

Andersen CL, Jensen JL, and TF Ø. 2004. Normalization of real-time quantitative reverse transcription-PCR data: a model-based variance estimation approach to identify genes suited for normalization, applied to bladder and colon cancer data sets. Cancer Research 64:5245-5250.

Bangaru MLY, Park F, Hudmon A, McCallum JB, and Hogan QH. 2012. Quantification of gene expression after painful nerve injury: validation of optimal reference genes. Journal of Molecular Neuroscience, 46:497-504.

Barsalobres-Cavallari CF, Severino FE, Maluf MP, and Maia IG. 2009. Identification of suitable internal control genes for expression studies in Coffea arabica under different experimental conditions. BMC Molecular Biology 10:1.

Bonnet M, Bernard L, Bes S, and Leroux C. 2013. Selection of reference genes for quantitative real-time PCR normalisation in adipose tissue, muscle, liver and mammary gland from ruminants. Animal 7:1344-1353.

Boutinaud M, Shand JH, Park MA, Phillips K, Beattie J, Flint DJ, and Allan GJ. 2004. A quantitative RT-PCR study of the mRNA expression profile of the IGF axis during mammary gland development. Journal of Molecular Endocrinology 33:195-207.

Browne GJ, and Proud CG. 2002. Regulation of peptide-chain elongation in mammalian cells. European Journal of Biochemistry 269:5360-5368.

Bustin SA. 2009. Why the need for qPCR publication guidelines?-The case for MIQE. Methods 50:217-226.

Bustin SA, Benes V, Garson JA, Hellemans J, Huggett J, Kubista M, Mueller R, Nolan T, Pfaffl MW, and Shipley GL. 2009. The MIQE guidelines: minimum information for publication of quantitative real-time PCR experiments. Clinical Chemistry 55:611-622.

Bustin SA, Benes V, Nolan T, and Pfaffl MW. 2005. Quantitative real-time RT-PCR--a perspective. Journal of Molecular Endocrinology 34:597-601.

Butte AJ, Dzau VJ, and Glueck SB. 2002. Further defining housekeeping, or "maintenance," genes focus on "A compendium of gene expression in normal human tissues". Physiological Genomics 7:95-96.

Costa JJ, Passos MJ, Leitão CC, Vasconcelos GL, Saraiva MV, Figueiredo JR, Van dHR, and Silva JR. 2012. Levels of mRNA for bone morphogenetic proteins, their receptors and SMADs in goat ovarian follicles grown in vivo and in vitro. Reproduction Fertility \& Development 24:723-732.

Cuberoleon E, Ciocan CM, Minier C, and Rotchell JM. 2012. Reference gene selection for qPCR in mussel, Mytilus edulis, during gametogenesis and exogenous estrogen exposure. Environmental Science and Pollution Research 19:2728-2733.

Culha M, Bat L, Dogan A, and Dagli E. 2009. Ecology and distribution of the veined rapa whelk Rapana venosa (Valenciennes, 1846) in Sinop peninsula (Southern Central Black Sea), Turkey. Journal of Animal \& Veterinary Advances 8:51-58.

Dheda K, Huggett JF, Chang JS, Kim LU, Bustin SA, Johnson MA, Rook GAW, and Zumla A. 2005. The implications of using an inappropriate reference gene for real-time reverse transcription PCR data normalization. Analytical Biochemistry 344:141-143.

Dheilly NM, Lelong C, Huvet A, and Favrel P. 2011. Development of a Pacific oyster (Crassostrea gigas) 31,918-feature microarray: identification of reference genes and tissue-enriched expression patterns. BMC Genomics 12:468.

Du Y, Zhang L, Xu F, Huang B, Zhang G, and Li L. 2013. Validation of housekeeping genes as 
internal controls for studying gene expression during Pacific oyster (Crassostrea gigas) development by quantitative real-time PCR. Fish \& Shellfish Immunology 34:939-945.

Eisenberg E, and Levanon EY. 2003. Human housekeeping genes are compact. Trends in Genetics Tig 19:362-365.

Ejiri S. 2002. Moonlighting functions of polypeptide elongation factor 1: from actin bundling to zinc finger protein R1-associated nuclear localization. Bioscience Biotechnology \& Biochemistry 66:1-21.

Evans KM, Wortley AH, and Mann DG. 2007. An assessment of potential diatom "barcode" genes (cox 1, rbcL, 18S and ITS rDNA) and their effectiveness in determining relationships in Sellaphora (Bacillariophyta). Protist 158:349-364.

Fernández-Aparicio M, Huang K, Wafula EK, Honaas LA, Wickett NJ, Timko MP, Depamphilis CW, Yoder JI, and Westwood JH. 2013. Application of qRT-PCR and RNA-Seq analysis for the identification of housekeeping genes useful for normalization of gene expression values during Striga hermonthica development. Molecular Biology Reports 40:33953407.

Fernandes JM, Mommens M, Hagen O, Babiak I, and Solberg C. 2008. Selection of suitable reference genes for real-time PCR studies of Atlantic halibut development. Comparative Biochemistry \& Physiology Part B Biochemistry \& Molecular Biology 150:23-32.

Giberto DA, Bremec CS, Schejter L, Schiariti A, Mianzan H, and Acha EM. 2006. The invasive rapa whelk Rapana venosa (Valenciennes 1846): Status and potential ecological impacts in the Río de la Plata estuary, Argentina-Uruguay. Journal of Shellfish Research: 919924.

Heid CA, Stevens J, Livak KJ, and Williams PM. 1996. Real time quantitative PCR. Genome Research 6:986-994.

Hsiao LL, Dangond F, Yoshida T, Hong R, Jensen RV, Misra J, Dillon W, Lee KF, Clark KE, and Haverty P. 2001. A compendium of gene expression in normal human tissues. Physiological Genomics 7:97.

Huggett J, Dheda K, Bustin S, and Zumla A. 2005. Real-time RT-PCR normalisation; strategies and considerations. Genes \& Immunity 6:279-284.

Infante C, Matsuoka MP, Asensio E, Cañavate JP, Reith M, and Manchado M. 2008. Selection of housekeeping genes for gene expression studies in larvae from flatfish using real-time PCR. BMC Molecular Biology 9:28.

Jain M, Nijhawan A, Tyagi AK, and Khurana JP. 2006. Validation of housekeeping genes as internal control for studying gene expression in rice by quantitative real-time PCR. Biochemical \& Biophysical Research Communications 345:646-651.

Jarczak J, Kaba J, and Bagnicka E. 2014. The validation of housekeeping genes as a reference in quantitative Real Time PCR analysis: application in the milk somatic cells and frozen whole blood of goats infected with caprine arthritis encephalitis virus. Gene 549:280.

Kaweesi T, Kawuki R, Kyaligonza V, Baguma Y, Tusiime G, and Ferguson ME. 2014. Field evaluation of selected cassava genotypes for cassava brown streak disease based on symptom expression and virus load. Virology Journal 11:216.

Kubista M, Andrade JM, Bengtsson M, Forootan A, Jonák J, Lind K, Sindelka R, Sjöback R, Sjögreen B, and Strömbom L. 2006. The real-time polymerase chain reaction. Molecular Aspects of Medicine 27:95-125.

López-Landavery EA, Portillo-López A, Gallardo-Escárate C, and Del Río-Portilla MA. 2014. Selection of reference genes as internal controls for gene expression in tissues of red 
abalone Haliotis rufescens (Mollusca, Vetigastropoda; Swainson, 1822). Gene 549:258265.

Lee JM, Roche JR, Donaghy DJ, Thrush A, and Sathish P. 2010. Validation of reference genes for quantitative RT-PCR studies of gene expression in perennial ryegrass (Lolium perenne L.). BMC Molecular Biology 11:1-14.

Leppäkoski E, Gollasch S, and Olenin S. 2002. Invasive aquatic species of Europe. Distribution, Impacts and Management. Springer, Netherlands.

Liu C, Wu G, Huang X, Liu S, and Cong B. 2012. Validation of housekeeping genes for gene expression studies in an ice alga Chlamydomonas during freezing acclimation. Extremophiles Life under Extreme Conditions 16:419-425.

Lusumin, Zhenmin, Xiaoli, Chunhua, Fang, and Jianguang. 2008. mRNA differential display on gene expression in settlement metamorphosis process of Ruditapes philippinarum larvae. High Technology Letters (English Edition):332-336.

Mann R, and Harding JM. 2003. Salinity tolerance of larval Rapana venosa: implications for dispersal and establishment of an invading predatory gastropod on the North American Atlantic coast. The Biological Bulletin 204:96-103.

Mann R, Harding JM, and Westcott E. 2006. Occurrence of imposex and seasonal patterns of gameteogenesis in the invading veined rapa whelk Rapana venosa from Chesapeake Bay, USA. Marine Ecology Progress 310:129-138.

Mateo DR, Greenwood SJ, Araya MT, Berthe FC, Johnson GR, and Siah A. 2010. Differential gene expression of gamma-actin, Toll-like receptor 2 (TLR-2) and interleukin-1 receptorassociated kinase 4 (IRAK-4) in Mya arenaria hemocytes induced by in vivo infections with two Vibrio splendidus strains. Developmental \& Comparative Immunology 34(7): 710-714.

Mimida N, Kidou S, and Kotoda N. 2007. Constitutive expression of two apple (Malus X domestica Borkh.) homolog genes of like heterochromatin protein1 affects flowering time and whole-plant growth in transgenic Arabidopsis. Molecular Genetics and Genomics 278:295-305.

Morga B, Arzul I, Faury N, and Renault T. 2010. Identification of genes from flat oyster Ostrea edulis as suitable housekeeping genes for quantitative real time PCR. Fish \& Shellfish Immunology 29:937-945.

Nilsen TO, Jordal A-EO, Lie KK, Olsvik PA, and Ivar H. 2005. Evaluation of potential reference genes in real-time RT-PCR studies of Atlantic salmon. BMC Molecular Biology 6:21.

Pan Y, Qiu T, Zhang T, Wang P, and Ban S. 2013. Morphological studies on the early development of Rapana venosa. Journal of Fisheries of China 37:1503-1512.

Pfaffl MW, Tichopad A, Prgomet C, and Neuvians TP. 2004. Determination of stable housekeeping genes, differentially regulated target genes and sample integrity: BestKeeper--Excel-based tool using pair-wise correlations. Biotechnology Letters 26:509-515.

Ray DL, and Johnson JC. 2014. Validation of reference genes for gene expression analysis in olive (Olea europaea) mesocarp tissue by quantitative real-time RT-PCR. BMC Research Notes 7:1-12.

Robinson TL, Sutherland IA, and Sutherland J. 2007. Validation of candidate bovine reference genes for use with real-time PCR. Veterinary Immunology \& Immunopathology 115:160165.

Samadi L, and Steiner G. 2009. Involvement of Hox genes in shell morphogenesis in the 
557 encapsulated development of a top shell gastropod (Gibbula varia L.). Development Genes and Evolution 219:523-530.

Song H, Yu ZL, Sun LN, Xue DX, Zhang T, and Wang HY. 2016. Transcriptomic analysis of differentially expressed genes during larval development of Rapana venosa by digital gene expression profiling. G3-Genes Genomes Genetics 6:2181-2193.

Stürzenbaum SR, and Kille P. 2001. Control genes in quantitative molecular biological techniques: the variability of invariance. Comparative Biochemistry \& Physiology Part B Biochemistry \& Molecular Biology 130:281-289.

Thellin O, Zorzi W, Lakaye B, De BB, Coumans B, Hennen G, Grisar T, Igout A, and Heinen E. 1999. Housekeeping genes as internal standards: use and limits. Journal of Biotechnology 75:291-295.

Vandesompele J, Preter KD, Pattyn F, Poppe B, Roy NV, Paepe AD, and Speleman F. 2002. Accurate normalization of real-time quantitative RT-PCR data by geometric averaging of multiple internal control genes. Genome Biology 3.

Wan Q, Whang I, Choi CY, Lee JS, and Lee J. 2011. Validation of housekeeping genes as internal controls for studying biomarkers of endocrine-disrupting chemicals in disk abalone by real-time PCR. Comparative Biochemistry \& Physiology Part C Toxicology \& Pharmacology 153:259-268.

Wang Q, Zhang L, Zhao J, You L, and Wu H. 2012. Two goose-type lysozymes in Mytilus galloprovincialis: possible function diversification and adaptive evolution. PLoS One 7: e45148.

Yuan C-Y. 1992. Primary exploration on aquaculture of Rapana venosa. Fisheries Science 9:005.

Zhao Y, Chen M, Wang T, Sun L, Xu D, and Yang H. 2014. Selection of reference genes for qRT-PCR analysis of gene expression in sea cucumber Apostichopus japonicus during aestivation. Chinese Journal of Oceanology and Limnology 32:1248-1256. 
Table 1 Candidate housekeeping genes and their primer sequences for qRT-PCR.

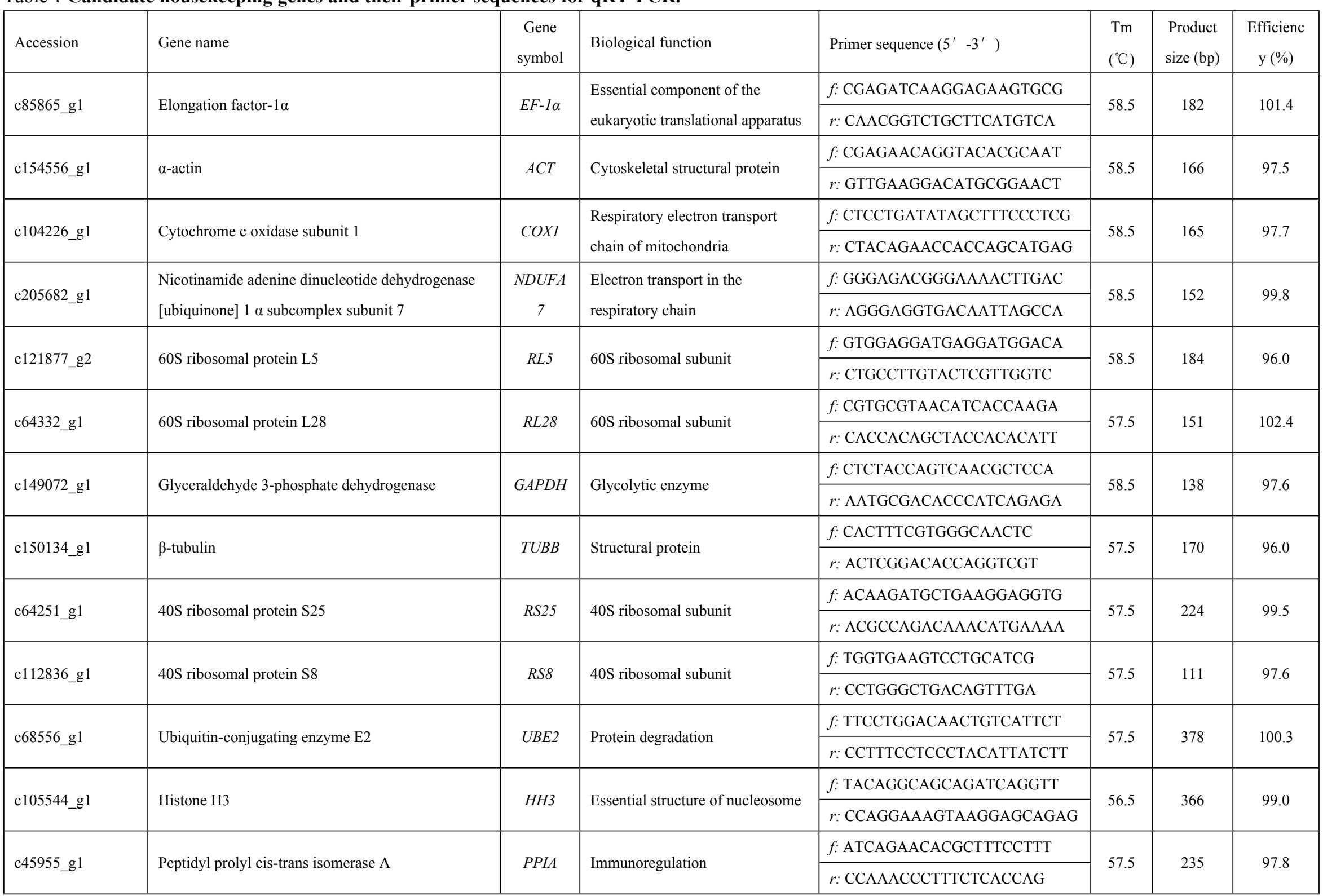


587

\begin{tabular}{llllllllll}
\hline Gene & All tissues & Gill & Hemocyte & Intestine & Leiblein & Liver & Kidney & Mantle & Gonad \\
\hline$E F-1 \alpha$ & $20.70 \pm 0.38$ & $19.14 \pm 0.36$ & $21.81 \pm 0.74$ & $23.00 \pm 1.35$ & $22.48 \pm 0.92$ & $20.35 \pm 0.46$ & $20.73 \pm 0.68$ & $16.98 \pm 0.61$ & $21.09 \pm 0.46$ \\
$A C T$ & $26.50 \pm 0.47$ & $25.20 \pm 0.45$ & $28.51 \pm 0.77$ & $29.24 \pm 1.35$ & $28.24 \pm 0.85$ & $26.88 \pm 0.52$ & $26.56 \pm 0.73$ & $20.57 \pm 0.44$ & $26.80 \pm 0.55$ \\
COX1 & $19.26 \pm 0.41$ & $17.36 \pm 0.31$ & $20.39 \pm 0.97$ & $21.47 \pm 1.25$ & $21.49 \pm 0.91$ & $18.57 \pm 0.56$ & $19.10 \pm 0.77$ & $15.36 \pm 0.48$ & $20.32 \pm 0.68$ \\
NDUFA7 $26.92 \pm 0.39$ & $24.69 \pm 0.32$ & $28.42 \pm 0.79$ & $29.49 \pm 1.19$ & $28.48 \pm 1.00$ & $26.54 \pm 0.56$ & $27.40 \pm 0.60$ & $23.41 \pm 0.73$ & $26.94 \pm 0.47$ \\
$R L 5$ & $23.14 \pm 0.41$ & $21.92 \pm 0.42$ & $24.19 \pm 0.81$ & $25.91 \pm 1.45$ & $24.57 \pm 0.95$ & $22.83 \pm 0.44$ & $23.89 \pm 0.67$ & $18.74 \pm 0.58$ & $23.05 \pm 0.53$ \\
$R L 28$ & $22.59 \pm 0.37$ & $21.47 \pm 0.41$ & $23.65 \pm 0.52$ & $24.96 \pm 1.19$ & $24.18 \pm 0.87$ & $22.13 \pm 0.42$ & $23.42 \pm 0.75$ & $18.63 \pm 0.58$ & $22.31 \pm 0.61$ \\
GAPDH & $24.14 \pm 0.42$ & $21.60 \pm 0.44$ & $24.18 \pm 0.71$ & $26.95 \pm 1.11$ & $24.98 \pm 0.95$ & $24.19 \pm 0.54$ & $24.72 \pm 0.59$ & $20.11 \pm 0.63$ & $26.44 \pm 0.84$ \\
TUBB & $25.95 \pm 0.43$ & $23.16 \pm 0.58$ & $26.72 \pm 0.35$ & $25.78 \pm 1.37$ & $24.95 \pm 0.72$ & $23.42 \pm 0.78$ & $26.08 \pm 0.80$ & $28.00 \pm 0.71$ & $29.48 \pm 1.33$ \\
$P P I A$ & $25.56 \pm 0.41$ & $24.43 \pm 0.35$ & $26.15 \pm 0.57$ & $28.41 \pm 1.19$ & $26.74 \pm 1.03$ & $24.78 \pm 0.72$ & $25.32 \pm 0.56$ & $21.67 \pm 0.71$ & $26.99 \pm 1.20$ \\
$R S 25$ & $24.95 \pm 0.39$ & $24.27 \pm 0.26$ & $24.95 \pm 0.42$ & $27.18 \pm 1.39$ & $26.22 \pm 0.91$ & $24.42 \pm 0.62$ & $25.70 \pm 0.80$ & $20.59 \pm 0.45$ & $26.30 \pm 0.82$ \\
UBE2 & $26.75 \pm 0.48$ & $24.49 \pm 0.46$ & $26.60 \pm 0.79$ & $29.71 \pm 1.46$ & $28.58 \pm 0.85$ & $26.65 \pm 0.57$ & $27.19 \pm 1.11$ & $22.09 \pm 0.88$ & $28.67 \pm 1.18$ \\
$R S 8$ & $24.15 \pm 0.43$ & $22.95 \pm 0.61$ & $24.45 \pm 0.77$ & $26.74 \pm 1.52$ & $25.80 \pm 0.79$ & $23.50 \pm 0.57$ & $24.57 \pm 0.85$ & $19.81 \pm 0.55$ & $25.42 \pm 0.97$ \\
$H H 3$ & $30.36 \pm 0.41$ & $28.45 \pm 0.42$ & $30.13 \pm 0.69$ & $32.84 \pm 0.44$ & $32.25 \pm 0.80$ & $30.58 \pm 0.53$ & $30.48 \pm 0.78$ & $26.04 \pm 1.05$ & $32.14 \pm 0.93$ \\
\hline
\end{tabular}

Table 2 Tissue-specific expression profiles of candidate reference genes. Data are shown as raw Cq values and represented as mean \pm standard error (SE).$$
91
$$ 
592 Table 3 Ranking of candidate reference genes in order of expression stability calculated by BestKeeper for different tissues. Data shown as Pearson 593 correlation coefficient (r) and standard deviation (SD).

\begin{tabular}{|c|c|c|c|c|c|c|c|c|c|c|c|c|c|c|c|c|c|c|}
\hline \multirow{2}{*}{ Rank } & \multicolumn{2}{|c|}{ All tissues } & \multicolumn{2}{|l|}{ Gill } & \multicolumn{2}{|c|}{ Hemocyte } & \multicolumn{2}{|l|}{ Intestine } & \multicolumn{2}{|l|}{ Leiblein } & \multicolumn{2}{|l|}{ Liver } & \multicolumn{2}{|l|}{ Kidney } & \multicolumn{2}{|l|}{ Mantle } & \multicolumn{2}{|l|}{ Gonad } \\
\hline & SD & $\mathrm{r}$ & SD & $\mathrm{r}$ & SD & $\mathrm{r}$ & SD & $\mathrm{r}$ & SD & $\mathrm{r}$ & SD & $\mathrm{r}$ & SD & $\mathrm{r}$ & SD & $\mathrm{r}$ & SD & $\mathrm{r}$ \\
\hline 1 & $R L 28$ & $E F-1 \alpha$ & $R S 25$ & $E F-1 \alpha$ & $T U B B$ & $R L 5$ & $H H 3$ & COXI & $T U B B$ & $E F-1 \alpha$ & $R L 28$ & PPIA & PPIA & $E F-1 \alpha$ & $R S 25$ & $E F-1 \alpha$ & $\begin{array}{l}\text { NDUFA } \\
7\end{array}$ & $E F-1 \alpha$ \\
\hline 2 & $E F-1 \alpha$ & $R S 8$ & COXI & $R S 8$ & $R S 25$ & $R L 28$ & $G A P D H$ & $T U B B$ & $R S 8$ & $R L 28$ & GAPDH & $R L 5$ & $G A P D H$ & $R L 5$ & COXI & $R L 5$ & $E F-1 \alpha$ & $R S 8$ \\
\hline 3 & $R S 25$ & $R L 28$ & $\begin{array}{l}\text { NDUFA } \\
7\end{array}$ & $R L 28$ & $R L 28$ & GAPDH & $\begin{array}{l}\text { NDUFA } \\
7\end{array}$ & $R L 5$ & COXI & $U B E 2$ & $R L 5$ & $\begin{array}{l}\text { NDUFA } \\
7\end{array}$ & $\begin{array}{l}\text { NDUFA } \\
7\end{array}$ & $U B E 2$ & $A C T$ & COXI & $R L 5$ & $R L 28$ \\
\hline 4 & $R L 5$ & $R L 5$ & $E F-1 \alpha$ & $R L 5$ & PPIA & $E F-1 \alpha$ & $R L 28$ & $E F-1 \alpha$ & $A C T$ & $R L 5$ & $E F-1 \alpha$ & $E F-1 \alpha$ & $R L 5$ & PPIA & $R L 28$ & PPIA & $A C T$ & $R L 5$ \\
\hline 5 & $\begin{array}{l}\text { NDUFA } \\
7\end{array}$ & COXI & PPIA & COXI & $R S 8$ & $A C T$ & PPIA & $R L 28$ & $U B E 2$ & GAPDH & $H H 3$ & COXI & $R L 28$ & $\begin{array}{l}\text { NDUFA } \\
7\end{array}$ & $R L 5$ & $R L 28$ & COXI & COXI \\
\hline 6 & PPIA & $U B E 2$ & $A C T$ & PPIA & $E F-1 \alpha$ & $\begin{array}{l}\text { NDUFA } \\
7\end{array}$ & COXI & PPIA & $R L 28$ & $T U B B$ & UBE2 & $R S 8$ & $E F-1 \alpha$ & $A C T$ & $E F-1 \alpha$ & UBE2 & $R L 28$ & PPIA \\
\hline 7 & $H H 3$ & PPIA & $H H 3$ & $A C T$ & $A C T$ & $R S 8$ & $A C T$ & $R S 25$ & $R S 25$ & $R S 8$ & $R S 8$ & $R L 28$ & $A C T$ & RL28 & $R S 8$ & $\begin{array}{l}\text { NDUFA } \\
7\end{array}$ & $R S 25$ & $A C T$ \\
\hline 8 & $R S 8$ & $R S 25$ & RL28 & $H H 3$ & GAPDH & COXI & $E F-1 \alpha$ & UBE2 & $\begin{array}{l}\text { NDUFA } \\
7\end{array}$ & $\begin{array}{l}\text { NDUFA } \\
7\end{array}$ & $A C T$ & $R S 25$ & $H H 3$ & $R S 25$ & GAPDH & $R S 8$ & $H H 3$ & $H H 3$ \\
\hline 9 & GAPDH & $\begin{array}{l}\text { NDUFA } \\
7\end{array}$ & $R L 5$ & UBE2 & $H H 3$ & PPIA & $R S 25$ & $A C T$ & GAPDH & $R S 25$ & $\begin{array}{l}\text { NDUFA } \\
7\end{array}$ & $A C T$ & $T U B B$ & COXI & PPIA & $H H 3$ & GAPDH & UBE2 \\
\hline 10 & COXI & GAPDH & GAPDH & $\begin{array}{l}\text { NDUFA } \\
7\end{array}$ & $R L 5$ & $H H 3$ & $T U B B$ & GAPDH & $E F-1 \alpha$ & $A C T$ & COXI & $T U B B$ & $R S 25$ & GAPDH & $T U B B$ & GAPDH & $R S 8$ & $\begin{array}{l}\text { NDUFA } \\
7\end{array}$ \\
\hline 11 & $T U B B$ & $A C T$ & UBE2 2 & $R S 25$ & $\begin{array}{l}\text { NDUFA } \\
7\end{array}$ & UBE2 & $R L 5$ & $R S 8$ & $H H 3$ & COXI & $R S 25$ & $U B E 2$ & COXI & $R S 8$ & $\begin{array}{l}\text { NDUFA } \\
7\end{array}$ & $R S 25$ & UBE2 & $R S 25$ \\
\hline 12 & $A C T$ & $H H 3$ & $T U B B$ & GAPDH & $U B E 2$ & $R S 25$ & UBE2 & $\begin{array}{l}\text { NDUFA } \\
7\end{array}$ & $R L 5$ & PPIA & $T U B B$ & GAPDH & $R S 8$ & TUBB & $U B E 2$ & $T U B B$ & PPIA & $G A P D H$ \\
\hline 13 & UBE2 & TUBB & $R S 8$ & $T U B B$ & COXI & $T U B B$ & $R S 8$ & $H H 3$ & PPIA & $H H 3$ & PPIA & HH3 & $U B E 2$ & $H H 3$ & HH3 & $A C T$ & $T U B B$ & TUBB \\
\hline
\end{tabular}


597 Table 4 Results from BestKeeper descriptive statistical analysis and BestKeeper regression analysis in different tissues and developmental stages

598 (correlation coefficients between each control gene Cq and the BestKeeper Index). Geo Mean represents Geometric mean while AR Mean represents

599 Arithmetic mean $[\mathrm{Cq}]$. Tissues and developmental stages are represented as $\mathrm{T}$ and $\mathrm{D}$, respectively.

\begin{tabular}{|c|c|c|c|c|c|c|c|c|c|c|c|c|c|c|c|c|c|c|c|c|c|c|c|c|c|c|}
\hline & \multicolumn{2}{|l|}{$E F-1 \alpha$} & \multicolumn{2}{|l|}{$A C T$} & \multicolumn{2}{|l|}{ COXI } & \multicolumn{2}{|c|}{ NDUFA7 } & \multicolumn{2}{|l|}{$R L 5$} & \multicolumn{2}{|l|}{ RL28 } & \multicolumn{2}{|c|}{ GAPDH } & \multicolumn{2}{|l|}{$T U B B$} & \multicolumn{2}{|l|}{$P P I A$} & \multicolumn{2}{|l|}{$R S 25$} & \multicolumn{2}{|l|}{$U B E 2$} & \multicolumn{2}{|l|}{$R S 8$} & \multicolumn{2}{|l|}{ ннз } \\
\hline & $\mathrm{T}$ & D & $\mathrm{T}$ & D & $\mathrm{T}$ & D & $\mathrm{T}$ & D & $\mathrm{T}$ & D & $\mathrm{T}$ & D & $\mathrm{T}$ & D & $\mathrm{T}$ & D & $\mathrm{T}$ & D & $\mathrm{T}$ & D & $\mathrm{T}$ & $\mathrm{D}$ & $\mathrm{T}$ & D & $\mathrm{T}$ & D \\
\hline $\mathrm{n}$ & 40 & 60 & 40 & 60 & 40 & 60 & 40 & 60 & 40 & 60 & 40 & 60 & 40 & 60 & 40 & 60 & 40 & 60 & 40 & 60 & 40 & 60 & 40 & 60 & 40 & 60 \\
\hline Geo Mean $[\mathrm{Cq}]$ & 20.56 & 18.95 & 26.33 & 24.39 & 19.09 & 19.09 & 26.81 & 25.88 & 22.99 & 22.74 & 22.47 & 22.63 & 24.00 & 22.79 & 25.81 & 22.70 & 25.43 & 25.36 & 24.83 & 25.25 & 26.58 & 26.74 & 24.01 & 24.17 & 30.25 & 28.40 \\
\hline AR Mean $[\mathrm{Cq}]$ & 20.70 & 19.12 & 26.50 & 24.61 & 19.26 & 19.29 & 26.92 & 26.00 & 23.14 & 22.91 & 22.59 & 22.80 & 24.14 & 22.93 & 25.95 & 23.09 & 25.56 & 25.50 & 24.95 & 25.44 & 26.75 & 26.90 & 24.15 & 24.39 & 30.36 & 28.51 \\
\hline $\min [\mathrm{Cq}]$ & 15.79 & 15.89 & 19.33 & 20.50 & 14.24 & 14.71 & 22.13 & 22.60 & 17.54 & 18.80 & 17.39 & 18.85 & 18.13 & 18.81 & 21.64 & 17.63 & 19.96 & 21.45 & 19.63 & 21.02 & 20.87 & 22.79 & 18.65 & 19.62 & 23.56 & 24.72 \\
\hline $\max [\mathrm{Cq}]$ & 27.26 & 25.67 & 33.86 & 32.70 & 25.34 & 25.40 & 32.45 & 32.41 & 30.57 & 29.67 & 28.72 & 28.76 & 29.84 & 29.89 & 32.73 & 33.20 & 31.46 & 32.15 & 31.12 & 32.31 & 33.62 & 32.85 & 31.61 & 31.89 & 34.08 & 33.45 \\
\hline $\mathrm{SD}[ \pm \mathrm{Cq}]$ & 1.88 & 2.30 & 2.24 & 2.98 & 2.11 & 2.52 & 1.93 & 2.27 & 1.90 & 2.54 & 1.79 & 2.59 & 2.09 & 2.24 & 2.17 & 3.79 & 1.99 & 2.39 & 1.88 & 2.81 & 2.39 & 2.64 & 2.07 & 2.99 & 2.06 & 2.20 \\
\hline $\mathrm{CV}[\% \mathrm{Cq}]$ & 9.08 & 12.02 & 8.46 & 12.10 & 10.96 & 13.04 & 7.15 & 8.73 & 8.21 & 11.09 & 7.93 & 11.34 & 8.65 & 9.75 & 8.36 & 16.43 & 7.79 & 9.36 & 7.54 & 11.05 & 8.94 & 9.82 & 8.58 & 12.27 & 6.79 & 7.71 \\
\hline $\min [x-$-fold $]$ & -27.35 & -8.37 & -127.64 & -14.85 & -28.81 & -20.86 & -25.66 & -9.71 & -43.81 & -15.38 & -33.88 & -13.78 & -58.46 & -15.73 & -18.02 & -33.51 & -44.43 & -15.02 & -36.79 & -18.81 & -52.21 & -15.50 & -41.00 & -23.48 & -103.17 & -12.86 \\
\hline $\max [\mathrm{x}$-fold $]$ & 103.71 & 105.07 & 185.34 & 316.90 & 76.20 & 79.21 & 49.82 & 92.41 & 190.90 & 121.70 & 76.00 & 69.80 & 57.31 & 137.63 & 120.96 & 1451.54 & 65.19 & 110.77 & 78.17 & 133.14 & 131.93 & 68.88 & 194.32 & 210.36 & 14.23 & 33.02 \\
\hline $\operatorname{std} \operatorname{dev}[ \pm x$-fold $]$ & 3.68 & 4.92 & 4.73 & 7.87 & 4.32 & 5.72 & 3.80 & 4.82 & 3.73 & 5.82 & 3.46 & 6.01 & 4.25 & 4.71 & 4.50 & 13.87 & 3.98 & 5.24 & 3.69 & 7.02 & 5.24 & 6.24 & 4.20 & 7.96 & 4.17 & 4.59 \\
\hline Coeff. of corr[r] & 0.96 & 0.98 & 0.92 & 0.98 & 0.95 & 0.99 & 0.93 & 0.99 & 0.95 & 0.99 & 0.95 & 1.00 & 0.93 & 0.95 & 0.30 & 0.96 & 0.94 & 0.98 & 0.94 & 0.99 & 0.95 & 0.99 & 0.96 & 0.99 & 0.87 & 0.87 \\
\hline Coeff. of $\operatorname{det}\left[r^{2}\right]$ & 0.93 & 0.95 & 0.84 & 0.96 & 0.90 & 0.98 & 0.87 & 0.97 & 0.90 & 0.98 & 0.91 & 0.99 & 0.87 & 0.91 & 0.09 & 0.93 & 0.88 & 0.96 & 0.88 & 0.98 & 0.90 & 0.97 & 0.92 & 0.98 & 0.75 & 0.75 \\
\hline$P$ value & 0.001 & 0.001 & 0.001 & 0.001 & 0.001 & 0.001 & 0.001 & 0.001 & 0.001 & 0.001 & 0.001 & 0.001 & 0.001 & 0.001 & 0.06 & 0.06 & 0.001 & 0.001 & 0.001 & 0.001 & 0.001 & 0.001 & 0.001 & 0.001 & 0.001 & 0.001 \\
\hline
\end{tabular}




\begin{tabular}{lllllll}
\hline Gene & All stages & Stage 1 & Stage 2 & Stage 3 & Stage 4 & Stage 5 \\
\hline GAPDH & $22.93 \pm 0.35$ & $26.39 \pm 0.54$ & $22.83 \pm 0.64$ & $21.43 \pm 0.22$ & $21.32 \pm 0.21$ & $20.61 \pm 0.48$ \\
EF-1 $\alpha$ & $19.12 \pm 0.34$ & $22.35 \pm 0.39$ & $19.59 \pm 0.65$ & $17.26 \pm 0.19$ & $17.05 \pm 0.20$ & $17.80 \pm 0.51$ \\
$A C T$ & $24.61 \pm 0.43$ & $29.09 \pm 0.44$ & $25.02 \pm 0.73$ & $22.23 \pm 0.22$ & $22.38 \pm 0.20$ & $21.50 \pm 0.51$ \\
COX1 & $19.29 \pm 0.36$ & $22.93 \pm 0.32$ & $19.71 \pm 0.68$ & $16.87 \pm 0.18$ & $17.70 \pm 0.17$ & $17.49 \pm 0.33$ \\
NDUFA7 & $26.00 \pm 0.34$ & $29.41 \pm 0.41$ & $26.29 \pm 0.58$ & $23.90 \pm 0.19$ & $24.69 \pm 0.11$ & $23.86 \pm 0.38$ \\
$R L 5$ & $22.91 \pm 0.37$ & $26.73 \pm 0.38$ & $23.10 \pm 0.67$ & $20.63 \pm 0.20$ & $21.24 \pm 0.11$ & $21.07 \pm 0.33$ \\
RL28 & $22.80 \pm 0.37$ & $26.67 \pm 0.31$ & $23.17 \pm 0.64$ & $20.33 \pm 0.17$ & $21.07 \pm 0.12$ & $21.02 \pm 0.24$ \\
TUBB & $23.09 \pm 0.57$ & $29.46 \pm 0.66$ & $22.82 \pm 0.77$ & $19.03 \pm 0.15$ & $20.09 \pm 0.10$ & $22.98 \pm 0.28$ \\
RS25 & $25.44 \pm 0.41$ & $29.90 \pm 0.37$ & $25.48 \pm 0.69$ & $22.92 \pm 0.15$ & $23.52 \pm 0.08$ & $23.32 \pm 0.19$ \\
$R S 8$ & $24.39 \pm 0.44$ & $29.02 \pm 0.45$ & $24.55 \pm 0.75$ & $21.48 \pm 0.17$ & $22.76 \pm 0.11$ & $22.08 \pm 0.37$ \\
UBE2 & $26.90 \pm 0.38$ & $30.83 \pm 0.37$ & $27.35 \pm 0.66$ & $24.35 \pm 0.17$ & $25.47 \pm 0.11$ & $24.22 \pm 0.25$ \\
PPIA & $25.50 \pm 0.36$ & $29.27 \pm 0.38$ & $25.51 \pm 0.62$ & $23.10 \pm 0.22$ & $24.57 \pm 0.10$ & $23.30 \pm 0.21$ \\
HH3 & $28.51 \pm 0.32$ & $31.45 \pm 0.33$ & $29.17 \pm 0.66$ & $26.41 \pm 0.19$ & $27.25 \pm 0.17$ & $26.50 \pm 0.30$ \\
\hline
\end{tabular}
error (SE).

606 
609

\begin{tabular}{|c|c|c|c|c|c|c|c|c|c|c|c|c|}
\hline \multirow{2}{*}{$\begin{array}{c}\text { Rank } \\
\text { position }\end{array}$} & \multicolumn{2}{|c|}{ All stages } & \multicolumn{2}{|c|}{ Stage 1} & \multicolumn{2}{|c|}{ Stage 2} & \multicolumn{2}{|c|}{ Stage 3} & \multicolumn{2}{|c|}{ Stage 4} & \multicolumn{2}{|c|}{ Stage 5} \\
\hline & $\mathrm{SD}$ & $\mathrm{r}$ & $\mathrm{SD}$ & $\mathrm{r}$ & $\mathrm{SD}$ & $\mathrm{r}$ & $\mathrm{SD}$ & $\mathrm{r}$ & SD & $\mathrm{r}$ & SD & $\mathrm{r}$ \\
\hline 1 & HH3 & $R L 28$ & $R L 28$ & PPIA & NDUFA7 & $R L 5$ & $T U B B$ & $R L 28$ & $R S 25$ & $T U B B$ & $R S 25$ & $G A P D H$ \\
\hline 2 & $G A P D H$ & $R L 5$ & $C O X 1$ & $R L 28$ & PPIA & $R L 28$ & $R S 25$ & NDUFA7 & NDUFA7 & $C O X 1$ & PPIA & $E F-1 \alpha$ \\
\hline 3 & NDUFA7 & $R S 25$ & HH3 & $R S 25$ & $H H 3$ & $R S 8$ & $U B E 2$ & $R L 5$ & $T U B B$ & $E F-1 \alpha$ & $U B E 2$ & $R L 5$ \\
\hline 4 & $E F-1 \alpha$ & $R S 8$ & $R L 5$ & $U B E 2$ & $G A P D H$ & $C O X 1$ & $R L 28$ & $C O X 1$ & $U B E 2$ & PPIA & $R L 28$ & $R L 28$ \\
\hline 5 & PPIA & $C O X 1$ & $E F-1 \alpha$ & $R S 8$ & $U B E 2$ & $T U B B$ & $C O X 1$ & $R S 8$ & $R S 8$ & $A C T$ & $H H 3$ & $R S 25$ \\
\hline 6 & $C O X 1$ & $U B E 2$ & $U B E 2$ & $T U B B$ & $E F-1 \alpha$ & $G A P D H$ & $R S 8$ & $R S 25$ & PPIA & NDUFA7 & $T U B B$ & $C O X 1$ \\
\hline 7 & $R L 5$ & NDUFA7 & $R S 25$ & $E F-1 \alpha$ & $R L 28$ & $E F-1 \alpha$ & NDUFA7 & $U B E 2$ & $R L 28$ & $R L 28$ & $C O X 1$ & NDUFA7 \\
\hline 8 & $R L 28$ & $A C T$ & NDUFA7 & NDUFA7 & $C O X 1$ & NDUFA7 & HH3 & $A C T$ & $R L 5$ & $U B E 2$ & $R L 5$ & $A C T$ \\
\hline 9 & $U B E 2$ & PPIA & $A C T$ & $R L 5$ & $R S 25$ & $A C T$ & $E F-1 \alpha$ & $E F-1 \alpha$ & $H H 3$ & $R L 5$ & $R S 8$ & $U B E 2$ \\
\hline 10 & $R S 25$ & $E F-1 \alpha$ & PPIA & $G A P D H$ & RL5 & $U B E 2$ & $R L 5$ & PPIA & $C O X 1$ & $R S 25$ & NDUFA7 & HH3 \\
\hline 11 & $A C T$ & $T U B B$ & $R S 8$ & $C O X 1$ & $A C T$ & $R S 25$ & $G A P D H$ & $H H 3$ & $A C T$ & $G A P D H$ & $G A P D H$ & $T U B B$ \\
\hline 12 & $R S 8$ & $G A P D H$ & $G A P D H$ & $A C T$ & $R S 8$ & PPIA & $A C T$ & $T U B B$ & $E F-1 \alpha$ & $H H 3$ & $A C T$ & PPIA \\
\hline 13 & $T U B B$ & HН3 & $T U B B$ & HН3 & $T U B B$ & НH3 & PPIA & $G A P D H$ & $G A P D H$ & $R S 8$ & $E F-1 \alpha$ & $R S 8$ \\
\hline
\end{tabular}

Table 6 Ranking of candidate reference genes in order of expression stability calculated by BestKeeper for different developmental stages. Data shown as Pearson correlation coefficient (r) and standard deviation (SD).

610

612 
subcluster_1, 455 genes

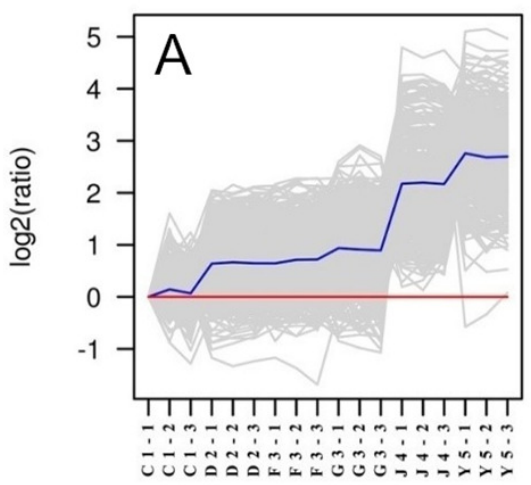

subcluster_4, 6092 genes

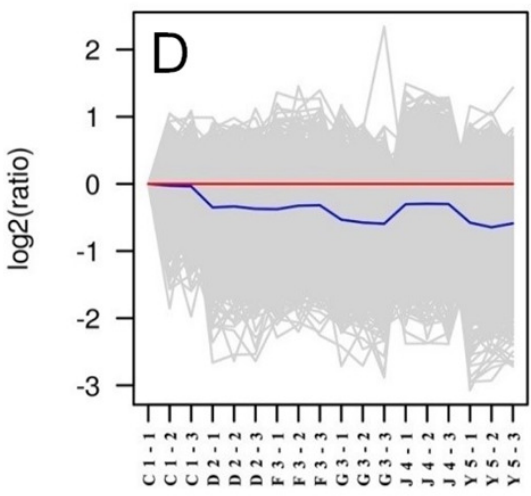

subcluster_7, 958 genes

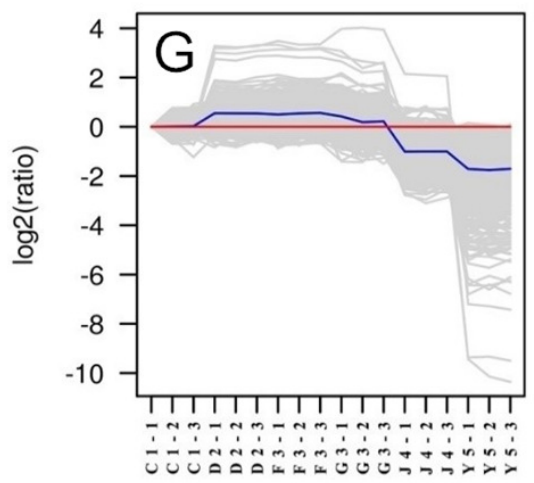

subcluster_2, 8222 genes

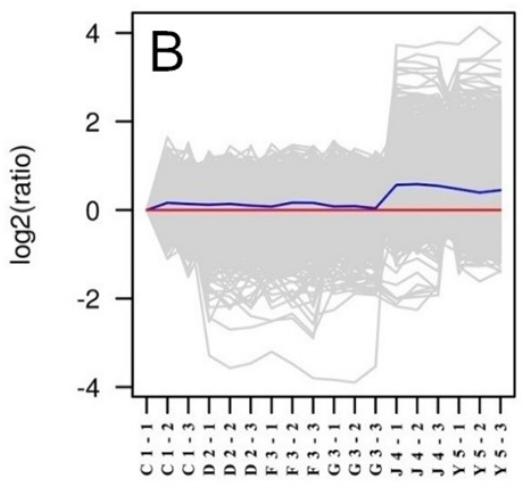

subcluster_5, 524 genes
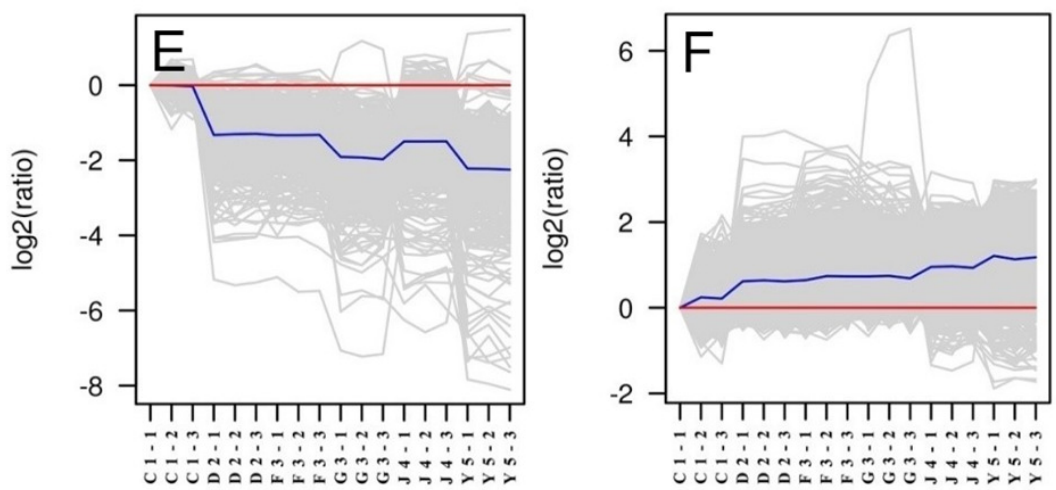

613

614

615

616
Figure 1 Clusters of genes in different developmental samples. Six developmental stages in triplicates consisting of one-spiral whorl stage (C), two-spiral whorl stage (D), early three-spiral whorl stage (F), late threespiral whorl stage (G), four-spiral whorl stage (J), and juveniles (Y). 

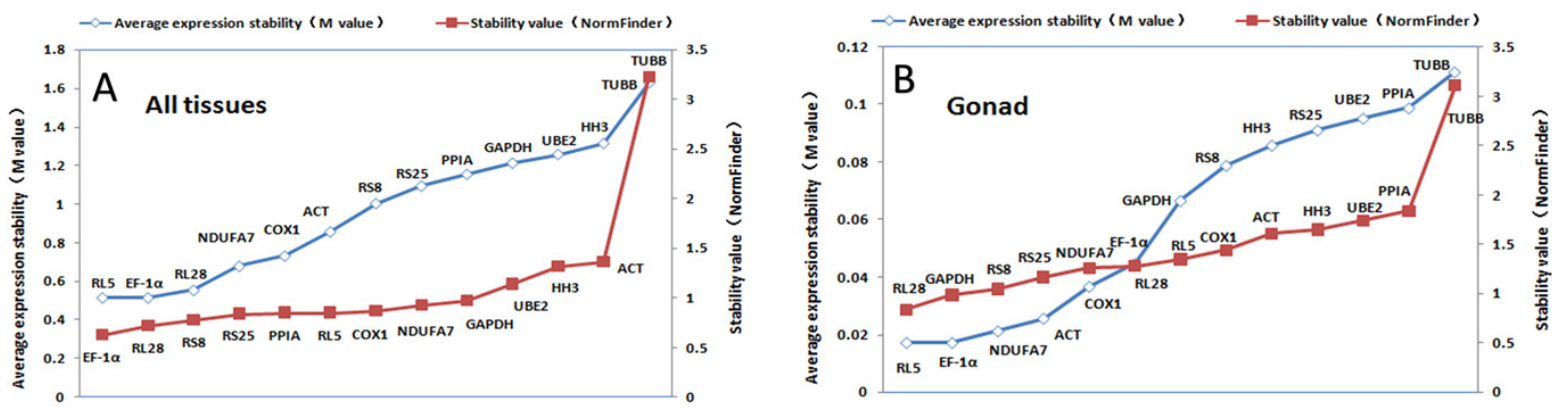

623

624

625

626

627

628

629

630

631

632

633

634

635

636

637

638

639

640

641

642

643

644

645

646

647

648

649

650

651

652

653

654
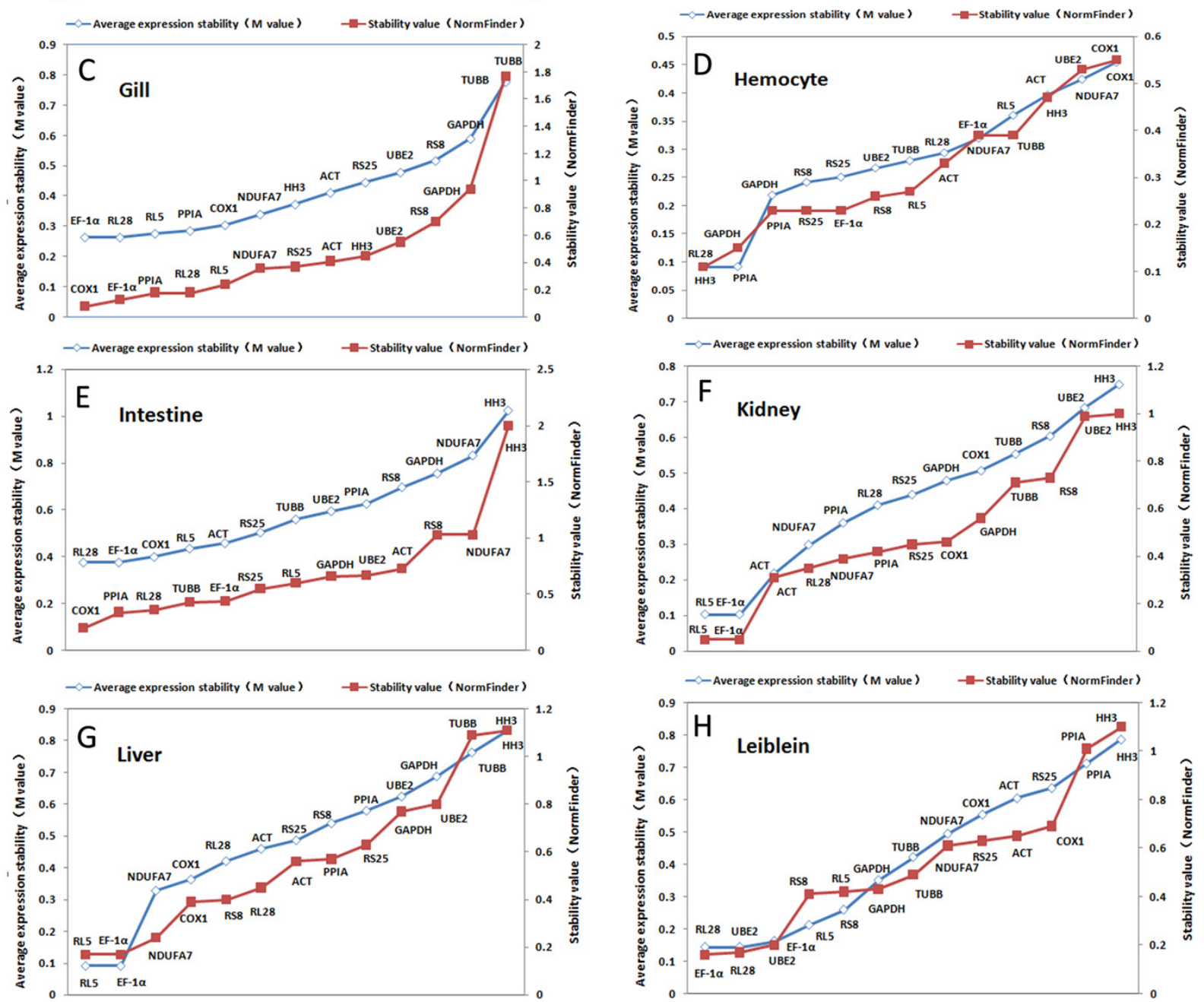

655

656

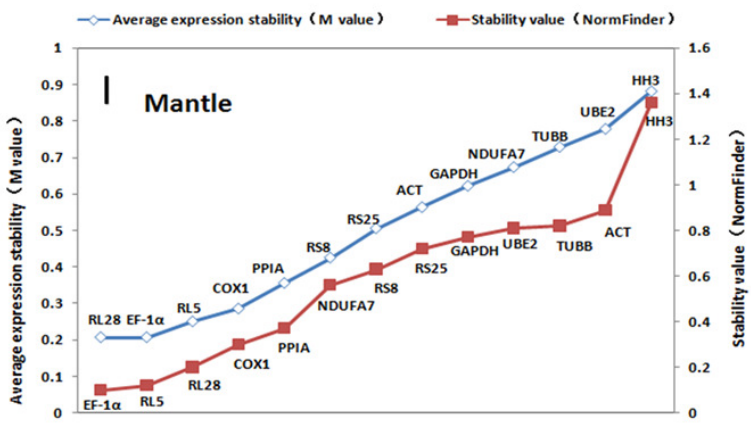

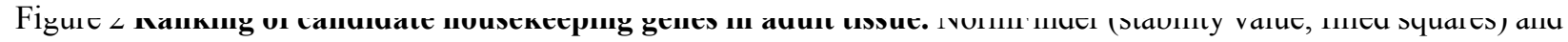

657 GeNorm [average expression stability ( $\mathrm{M}$ value) of remaining genes, open rhombus] ranking of candidate housekeeping genes in eight tissues together and separately. A lower value indicates more stable expression. 

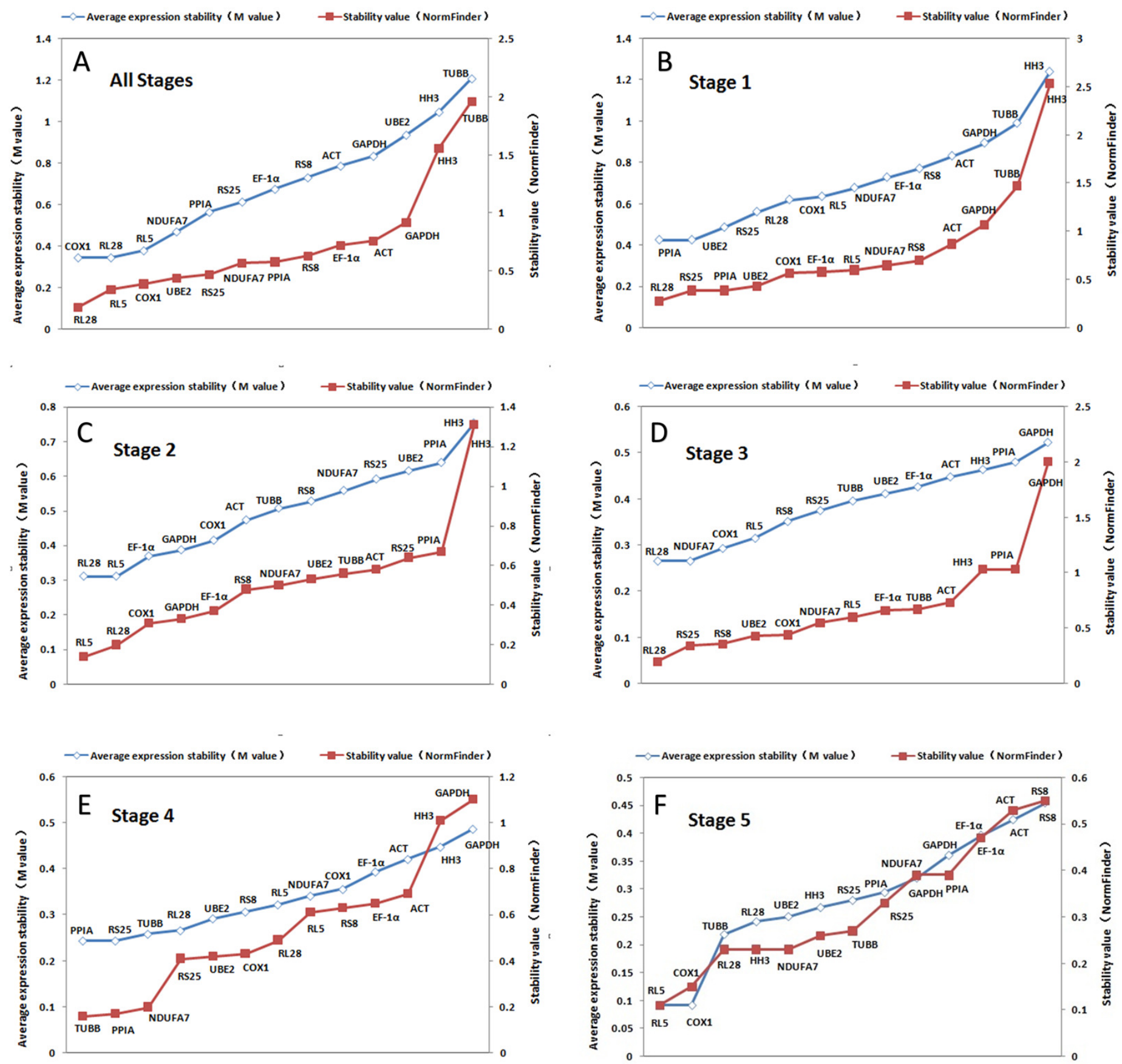

658 Figure 3 Ranking of candidate housekeeping genes in developmental stages. NormFinder (stability value, filled 659 squares) and GeNorm [average expression stability ( $M$ value) of remaining genes, open rhombus] ranking of 660 candidate housekeeping genes in five developmental stages together and separately. A lower value indicates more 661 stable expression. 
663

664

665

666

\section{3}

0.25

동

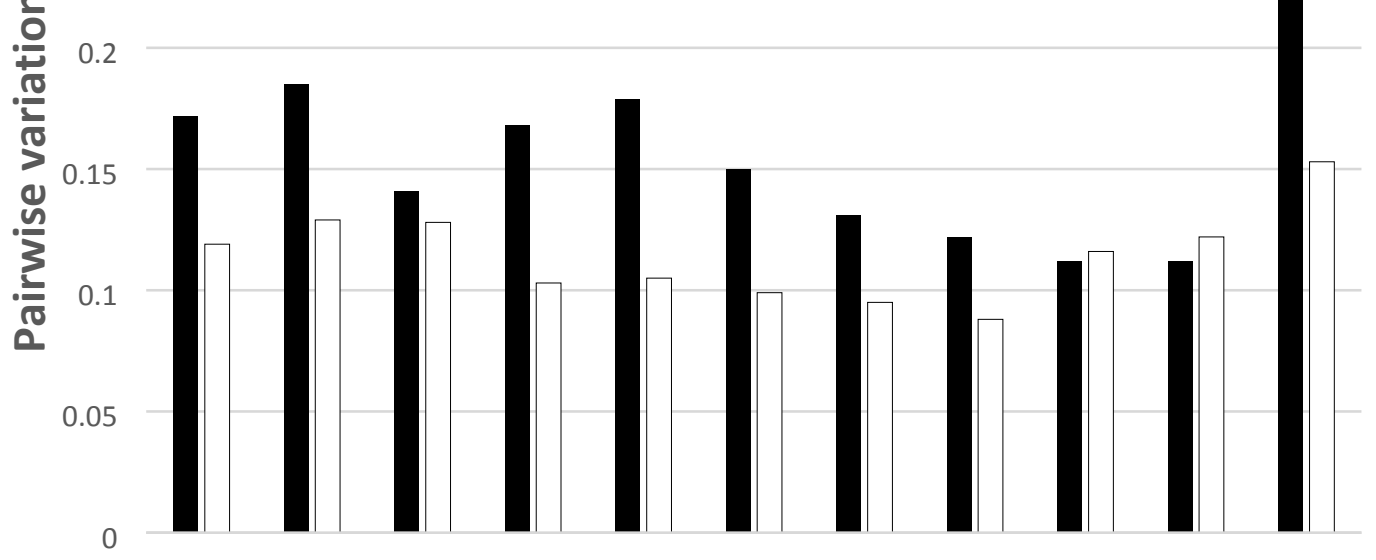

$\begin{array}{lllllllllll}V 2 / 3 & V 3 / 4 & V 4 / 5 & V 5 / 6 & V 6 / 7 & V 7 / 8 & V 8 / 9 & V 9 / 10 & V 10 / 11 & V 11 / 12 & V 12 / 13\end{array}$

- Tissues $\square$ Developmental stages

Figure 4 Determination of the number of reference genes required for accurate normalization. Pairwise variation by GeNorm between candidate genes in tissues (black bar) and developmental stages (white bar). 